\title{
Factors Influencing Aggregation and Adhesion of Oral Lactobacillus gasseri
}

\author{
Lata PLANSANGKET ${ }^{1,2}$, Rawee TEANPAISAN ${ }^{2,3}$ and Supatcharin PIWAT ${ }^{1,2, *}$ \\ ${ }^{1}$ Department of Preventive Dentistry, Faculty of Dentistry, Prince of Songkla University, \\ Songkhla 90112, Thailand \\ ${ }^{2}$ Common Oral Diseases and Epidemiology Research Center, Faculty of Dentistry, \\ Prince of Songkla University, Songkhla 90112, Thailand \\ ${ }^{3}$ Department of Stomatology, Faculty of Dentistry, Prince of Songkla University, \\ Songkhla 90112, Thailand
}

("Corresponding author’s e-mail: supacharin.p@psu.ac.th)

Received: 26 May 2019, Revised: 7 September 2020, Accepted: 30 October 2020

\begin{abstract}
Lactobacillus gasseri is one of the Lactobacillus species, which has been considered as an oral probiotic. The probiotic characters, e.g., the aggregation and adhesion abilities, may be affected by the changes in the oral environment. This study aimed to investigate the effect of cell surface components, some enzymes, $\mathrm{pH}$, sugars, and ions on the aggregation (auto-and coaggregation) abilities of oral L. gasseri and on the ability to adhere to oral epithelial cells. The control group contained the bacteria in pH 7.0 solution. The results indicated that the cell surface-related protein components were essential for the aggregation and internalized adhering abilities of $L$. gasseri. For environmental factors, amylase, calcium ion, and magnesium ion significantly increased both autoaggregation and coaggregation ability, while these abilities were significantly decreased by lactose. The coaggregation between $L$. gasseri and $S$. mutans ATCC $25175^{\mathrm{TM}}$ was significantly increased by $\mathrm{pH} 4.0$, whereas glucose, sucrose, trypsin, and lysozyme significantly decreased the coaggregation. The adhesion was significantly increased by $\mathrm{pH} 4.0$, $\mathrm{pH} 8.0$, calcium ion, and magnesium ion, whereas enzymes and sugars did not affect this ability. These traits could be used for the preliminary screening of the potential candidates of probiotics with possible anti-caries properties.
\end{abstract}

Keywords: Aggregation, Adhesion, Lactobacillus gasseri, Strptococcus mutans, Environmental factors

\section{Introduction}

Lactobacillus gasseri constitutes a major part of the homofermentative Lactobacillus species that are found in the oral cavity, gastrointestinal tract, and vagina [1]. L. gasseri has been identified from different sites in the oral cavity such as saliva, dental plaque, and periodontal tissue [2,3]. L. gasseri has been proposed as one of the predominant species commonly found in newborns and is one of the early colonizers in the gastrointestinal tract and existing throughout adulthood [4].

L. gasseri shows various health benefits through its antimicrobial activity, bacteriocin production, and immunomodulation of the innate and systemic immune responses [1]. Studies on the probiotic characteristics of L. gasseri suggested that the strain also exhibits antagonistic effects against gastrointestinal pathogens belonging to the genera Clostridium, Cronobacter, Helicobacter, and Campylobacter [5-7]. Moreover, L. gasseri has been reported to have protective effects against oral pathogens in in vitro and also in in vivo studies. Kobayashi et al. demonstrated that L. gasseri SBT2055 reduced alveolar bone loss, detachment, and disorganization of the periodontal ligament, and this strain was effective in preventing Porphyromonas gingivalis-accelerated periodontal disease [8]. Besides, 
http://wjst.wu.ac.th

another study reported that L.gasseri inhibited the growth of Streptococcus mutans, Streptococcus sobrinus, Actinomyces naeslundii, Actinomyces oris, Candida albicans, and Fusobacterium nucleatum [9].

The important characteristics of bacteria for colonization and existence in the oral cavity are the ability to adhere to host tissues and to aggregate to form biofilms or to take the advantage of the ecosystem [10]. These phenotypic traits are widely used for screening potentially probiotic strains. Auto aggregation and adhesion to host cells of probiotic strains appear to be necessary for forming a barrier. Coaggregation of probiotic strains with the pathogens is an important ability for displacing pathogens from the oral cavity and human gut [11-13]. Thus, potentially probiotic bacteria with these abilities may have the possibility to colonize, function stably in the host, and prevent the colonization of the pathogenic microorganisms.

A study of adhesion and aggregation abilities and the surface charges of various Lactobacillus species derived from the human oral cavity reported that L. gasseri strains showed high externalization and aggregation (auto- and coaggregation) abilities [11]. Variations of the adherence ability among species and strains may be related to the diversity of the response to stress factors in the host environment such as acid-base condition, enzyme, and substrate; these adaptations may help bacteria survive in the environmental conditions encountered in the oral cavity [14]. Moreover, different agents or environments may be able to block the adhesion and aggregation of bacteria $[15,16]$. The oral environment, which is constantly changing, may affect these binding properties of the oral bacterial cell surface. To gain an understanding of how bacteria aggregate or adhere to surfaces in such an environment, in vitro experiments research was conducted. The overall aim of the present study was to investigate the effect of cell surface components, some enzymes, $\mathrm{pH}$, sugars, and ions on the aggregation (auto- and coaggregation) abilities of oral L. gasseri and on the adhesion ability to oral epithelial cells.

\section{Materials and methods}

\section{Bacterial strains and culture conditions}

Seventeen strains of oral Lactobacillus gasseri were selected from the culture collection of the Department of Stomatology, Faculty of Dentistry, Prince of Songkla University, Thailand. The strains had initially been identified to species level from the previous study of Piwat et al. [17]. The prevalence of $L$. gasseri in our previous study was relatively low. However, most the strains come from low-caries children [17]. Before experimental use, the bacteria were grown on Man Rogosa Sharpe agar (MRS, Difco $^{\mathrm{TM}}$, USA) in an anaerobic condition $\left(80 \% \mathrm{~N}_{2}, 10 \% \mathrm{H}_{2}\right.$, and $\left.10 \% \mathrm{CO}_{2}\right)$ at $37{ }^{\circ} \mathrm{C}$ for $18-24 \mathrm{~h}$, and then transferred to Man Rogosa Sharpe broth (MRS, Himedia ${ }^{\circledR}$, India) for an additional $18-24 \mathrm{~h}$ incubation.

The cariogenic pathogen, $S$. mutans ATCC $25175^{\mathrm{TM}}$, was used in the aggregation assay. The strain was cultured on a blood agar plate $\left(\mathrm{BBL}^{\mathrm{TM}}\right.$, USA) for $18-24 \mathrm{~h}$, and transferred to Brain Heart Infusion broth (BHI, Bacto ${ }^{\mathrm{TM}}$, USA) in an aerobic condition $\left(5 \% \mathrm{CO}_{2}\right)$ at $37{ }^{\circ} \mathrm{C}$ for an additional $18-24 \mathrm{~h}$ incubation.

\section{Factors affecting adhesion and aggregation ability of bacterial cells}

The effect of the factors was determined according to the method of Lang et al. [18] with some modifications. Overnight cultures of L. gasseri and S. mutans ATCC $25175^{\mathrm{TM}}$ were harvested by centrifugation at 3,000 rpm for $10 \mathrm{~min}$ and washed twice with phosphate-buffered saline (PBS) $\mathrm{pH}$ 7.0. The cell pellets were treated in different solutions as follows: (i) chemical agents for cell surface component test: $10 \mathrm{mM}$ Metaperiodate in $0.1 \mathrm{M}$ citrate-phosphate buffer $(\mathrm{pH} 4.5), 5 \mathrm{M} \mathrm{LiCl}$ in distilled water, and Proteinase $\mathrm{K}$ in $50 \mathrm{mM}$ Tris- $\mathrm{HCl}$ buffer ( $\mathrm{pH} 7.5)$, (ii) enzyme solution ( $1 \mathrm{mg} / \mathrm{mL}$ ): Enzyme amylase in $15 \mathrm{mM}$ PBS ( $\mathrm{pH} 7.0$ ), lysozyme in Tris EDTA sucrose buffer (pH 8.0), trypsin in $50 \mathrm{mM}$

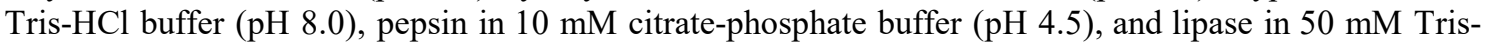
$\mathrm{HCl}$ buffer ( $\mathrm{pH} 8.0$ ), (iii) PBS buffer adjusted to $\mathrm{pH}(4.0,8.0)$, (iv) $50 \mathrm{mM}$ sugar (glucose, sucrose and lactose), (v) $10 \mathrm{mM}$ calcium or magnesium. The bacteria in PBS solution ( $\mathrm{pH} 7.0$ ) were used in the control group. 
http://wjst.wu.ac.th

Treated bacterial suspensions were mixed by vortexing. The optical density was measured at $600 \mathrm{~nm}$ $\left(\mathrm{OD}_{600 \mathrm{~nm}}\right)$ using a spectrophotometer (Ultrospec $2000^{\mathrm{TM}}$ ) to give viable counts of approximately $10^{10}$ $\mathrm{CFU} / \mathrm{mL}\left(\mathrm{OD}_{600 \mathrm{~nm}}=0.5\right)$ for aggregation assay and $10^{8} \mathrm{CFU} / \mathrm{mL}\left(\mathrm{OD}_{600 \mathrm{~nm}}=0.25\right)$ for adhesion assay.

\section{Autoaggregation and coaggregation assays}

Autoaggregation assay was performed according to Kos et al. [19] with some modification. The treated bacterial suspensions $\left(4 \mathrm{~mL}\right.$ ) were mixed by vortexing (Vortex-Genie $2^{\mathrm{TM}}$ ) for $10 \mathrm{~s}$ and auto aggregation was determined after $24 \mathrm{~h}$ of incubation at $37^{\circ} \mathrm{C}$. One milliliter of the upper layer of each tube was carefully removed after $24 \mathrm{~h}$. The absorbance of the supernatant was measured at $600 \mathrm{~nm}$. The percent of autoaggregation was expressed as follows:

$\%$ of autoaggregation $=\left(1-\mathrm{A}_{\text {time }} / \mathrm{A}_{\text {initial }}\right) \times 100$

where $A_{\text {time }}$ is the optical density of the upper layer of the suspensions at $24 \mathrm{~h}$ after incubation, $A_{\text {initial }}$ is the optical density of the suspensions at baseline.

Coaggregation assay between L. gasseri and S. mutans ATCC $25175^{\mathrm{TM}}$ was performed according to Piwat et al. (2015) [12]. Equal volumes $(2 \mathrm{~mL})$ of the treated L. gasseri and S. mutans ATCC $25175^{\mathrm{TM}}$ suspensions were mixed and vortexed for $10 \mathrm{~s}$. After incubation at $37{ }^{\circ} \mathrm{C}$ for $24 \mathrm{~h}$ to allow coaggregation to occur, $1 \mathrm{~mL}$ of the upper layer of the supernatant was carefully removed. Absorbance was measured at $600 \mathrm{~nm}$. The coaggregation percentage was expressed as:

$\%$ of coaggregation $\left.=\left[\left(\mathrm{A}_{\text {L.gasseri }}+\mathrm{A}_{\text {S. mutans }}\right) / 2\right]-\mathrm{A}_{\text {mix }}\right] /\left[\left(\mathrm{A}_{\text {L.gasseri }}+\mathrm{A}_{\text {S. mutans }}\right) / 2\right] \times 100$

where $\mathrm{A}_{\text {L.gasseri }}$ is the optical density of $L$. gasseri suspensions at initial time, $\mathrm{A}_{S \text {. mutans }}$ is the optical density of $S$. mutans ATCC $25175^{\mathrm{TM}}$ suspensions at initial time, $\mathrm{A}_{\text {mix }}$ is the optical density of the mixed L. gasseri and $S$. mutans ATCC $25175^{\mathrm{TM}}$ suspensions at $24 \mathrm{~h}$ after incubation.

\section{Adhesion to keratinocyte cells}

The adhesion activity of L. gasseri was assessed according to Kintarak et al. [20], using H357 keratinocyte cells as an oral squamous carcinoma cell line. The treated L. gasseri suspensions were added to H357 keratinocyte cells in Dulbecco's modified Eagle's medium (DMEM) on the 24-well plates. After incubation for $1 \mathrm{~h}$ at $37{ }^{\circ} \mathrm{C}$ in anaerobic condition, each well of the plates was washed twice with PBS ( $\mathrm{pH}$ 7.0)to remove free and nonattached bacterial cells. The adherent bacteria both extracellular (Externalization) and intracellular bacteria (Internalization) were counted as total adhesion.

For internalization assay, the treated L. gasseri and H357 monolayer cells in 24-well plates were prepared using the same protocol as above. Then, $1 \mathrm{~mL}$ of DMEM containing gentamicin $(100 \mu \mathrm{g} / \mathrm{mL})$ was added to each well to kill extracellular bacteria and incubated for $2 \mathrm{~h}$ at $37{ }^{\circ} \mathrm{C}$ under an anaerobic condition. After that, each well of the plates was washed twice with PBS (pH 7.0).

To determine the bacterial cell number, trypsin-EDTA was added to H357 monolayer cells and incubated at $37{ }^{\circ} \mathrm{C}$ for $10 \mathrm{~min}$. Then Triton X-100 was added to each well for keratinocyte cell lysis. After incubation for $15 \mathrm{~min}$ at $37{ }^{\circ} \mathrm{C}$, a ten-fold serial dilution of the suspension was plated onto MRS plates and incubated under anaerobic conditions at $37{ }^{\circ} \mathrm{C}$ for $48 \mathrm{~h}$ to measure the number of viable bacterial colonies. The percent adhesion was expressed as follows:

Externalization $(\mathrm{CFU} / \mathrm{mL})=$ Total adhesion $(\mathrm{CFU} / \mathrm{mL})-$ Internalization $(\mathrm{CFU} / \mathrm{mL})$

$\%$ Total adhesion or internalization or Externalization $=\left(\mathrm{A} / \mathrm{A}_{0}\right) \times 100$

where $\mathrm{A}_{0}=$ number of bacterial cells $(\mathrm{CFU} / \mathrm{mL})$ at the beginning, $\mathrm{A}=$ number of bacterial cells $(\mathrm{CFU} / \mathrm{mL})$ adhered totally or internalization or externalization 
http://wjst.wu.ac.th

\section{Statistical analysis}

All experiments were independently conducted twice. The results were expressed as means \pm standard deviation and median of the percentage of aggregation or adhesion. The Mann-Whitney $U$ test was applied to compare data from the control group and treated groups. The software package used for the analyses was the SPSS statistical program (SPSS Inc., Chicago, IL). Differences were considered significant when $p$-value $<0.05$.

\section{Results and discussion}

\section{Chemical treatments for cell surface component of $L$. gasseri}

Cell surface component is an important factor for the aggregation and adhesion of bacterial cells and may have strain-specific properties. The cell surface structure of lactobacilli contains a variety of components, including peptidoglycan, teichoic acids, exopolysaccharides, and proteins, which function through different mechanisms. Loss of specific cell surface elements can reduce these abilities [14].

In the present study, the oral L. gasseri strains showed $30-40 \%$ of the ability to internalization in keratinocyte cells. There are little data in the literature on Lactobacillus internalization; moreover, the study about the internalization of L. gasseri to keratinocyte cells is still limited. Nevertheless, the adhesion and invasion capacity to epithelial cells of the Lactobacillus strains from the vagina have been studied by Santos et al. [21]. They showed that L. gasseri was able to internalize in HeLa cells. Microscopy observations of HeLa cell monolayers revealed that cell monolayers incubated with the Lactobacillus strains remained intact and showed no visible changes when compared to the noninoculated control. As well, none of the Lactobacillus strains induced apoptosis in the HeLa cells [21]. In the present study, oral L. gasseri was subjected to chemical treatments, including proteinase $\mathrm{K}$, $\mathrm{LiCl}$, and metaperiodate, to characterize the cell surface components responsible for its aggregation and adhesion abilities. Proteinase $\mathrm{K}$ is a non-specific serine protease with a very high specific activity for general digestion of proteins. $\mathrm{LiCl}$ solution was used to remove the crystalline surface layer (S-layer) protein from the bacterial cell wall, while the contribution of carbohydrate molecule was examined by oxidizing cell surface carbohydrates with metaperiodate solution.

The results (Table 1) indicate that treatment with proteinase $\mathrm{K}$ had a highly significant effect on the aggregation abilities of $L$. gasseri as compared to the untreated samples. In the absence of surface-related proteins, the autoaggregation and coaggregation abilities were reduced from 70.09 and $50.94 \%$ to 49.13 and $41.59 \%$, respectively. L. gasseri treated with $\mathrm{LiCl}$ and metaperiodate showed no significant change in the ability for aggregation and adhesion as compared with controls. For adhesion ability, treatment of the cells with proteinase $\mathrm{K}$ significantly affected only the internalization, while no effect was seen on total adhesion or externalization abilities. The results suggested that the cell surface-related protein components are essential for the aggregation and internalized adhering abilities of the strains. Therefore, if bacterial cells are under conditions that affect the protein on the cell surface, they may show a reduction in properties. 
http://wjst.wu.ac.th

Table 1 Effect of chemical treatments for cell surface component on the aggregation and adhesion abilities of L. gasseri ${ }^{\mathrm{a}}$.

\begin{tabular}{|c|c|c|c|c|c|c|}
\hline \multirow[b]{2}{*}{ Factors } & \multicolumn{3}{|c|}{$\%$ Aggregation ability } & \multicolumn{3}{|c|}{$\%$ Adhesion ability ${ }^{\mathrm{c}}$} \\
\hline & $\begin{array}{c}\text { Autoaggregation } \\
\text { L. gasseri }\end{array}$ & $\begin{array}{c}\text { Autoaggregation } \\
\text { S. mutans }\end{array}$ & Coaggregation $^{b}$ & Total adhesion & Internalization & Externalization \\
\hline Control & $\begin{array}{c}70.09 \pm 9.50 \\
(69.76)\end{array}$ & $\begin{array}{c}35.75 \\
(33.10)\end{array}$ & $\begin{array}{l}50.94 \pm 7.15 \\
(52.81)\end{array}$ & $\begin{array}{c}67.73 \pm 11.22 \\
(68.83)\end{array}$ & $\begin{array}{c}40.72 \pm 11.82 \\
(37.83)\end{array}$ & $\begin{array}{l}27.01 \pm 8.30 \\
(26.19)\end{array}$ \\
\hline Proteinase $\mathrm{K}$ & $\begin{array}{c}49.13 \pm 7.82 \\
\left(47.38^{* *}\right)\end{array}$ & $\begin{array}{c}37.41 \\
(35.70)\end{array}$ & $\begin{array}{c}41.59 \pm 6.36 \\
\left(41.85^{* *}\right)\end{array}$ & $\begin{array}{c}64.43 \pm 5.52 \\
(64.30)\end{array}$ & $\begin{array}{c}33.36 \pm 6.63 \\
\left(32.94^{*}\right)\end{array}$ & $\begin{array}{c}31.07 \pm 5.48 \\
(32.37)\end{array}$ \\
\hline $\mathrm{LiCl}$ & $\begin{array}{c}64.89 \pm 6.82 \\
(63.24)\end{array}$ & $\begin{array}{c}41.10 \\
(41.30)\end{array}$ & $\begin{array}{c}47.06 \pm 6.81 \\
(46.61)\end{array}$ & $\begin{array}{c}61.32 \pm 8.92 \\
(61.74)\end{array}$ & $\begin{array}{l}35.78 \pm 8.05 \\
(36.55)\end{array}$ & $\begin{array}{l}25.52 \pm 6.18 \\
(27.58)\end{array}$ \\
\hline Metaperiodate & $\begin{array}{c}66.80 \pm 7.38 \\
(66.17)\end{array}$ & $\begin{array}{c}45.35 \\
(44.40)\end{array}$ & $\begin{array}{c}50.13 \pm 8.84 \\
(48.29)\end{array}$ & $\begin{array}{l}62.46 \pm 10.08 \\
(62.34)\end{array}$ & $\begin{array}{c}32.97 \pm 14.46 \\
(32.48)\end{array}$ & $\begin{array}{c}29.49 \pm 8.20 \\
(28.29)\end{array}$ \\
\hline
\end{tabular}

${ }^{\mathrm{a}}$ Data are expressed as mean $\pm \mathrm{SD}$ (median)

${ }^{\mathrm{b}}$ Coaggregation between L. gasseri strains and S. mutans ATCC $25175^{\mathrm{TM}}$

${ }^{c}$ Adhesion ability for L. gasseri strains with oral squamous carcinoma cell line, H357 keratinocyte cells, in Dulbecco's modified Eagle's medium

* Significant differences at $p$-value $<0.05$ between control and tested group

${ }^{* *}$ Significant differences at $p$-value $<0.001$ between control and tested group

\section{Effect of enzymatic treatments}

Probiotic bacteria should remain either in the oral cavity or GI tract to display the properties of probiotics. Some oral and GI tract enzymes were used to investigate the effect on bacterial cells (Table 2). The results showed that the aggregations were affected by some enzymatic treatments while the adhesion was not affected. The oral enzymes amylase, which is the main enzyme in saliva that breaks carbohydrates (starches) down to maltose, and lysozyme, a prominent antimicrobial protein of human saliva, were used for testing. The amylase enzyme significantly increased both autoaggregation and coaggregation capabilities compared to buffer controls. As a result of the antibacterial activity, lysozyme can cause the degradation of the peptidoglycan-containing layer of bacterial cell wall, ultimately resulting in bacterial lysis [22]. The lysis of Gram-positive bacteria with lysozyme is species and strain specific $[23,24]$. According to Chassy et al., the study showed each strain of $S$. mutans and Lactobacillus spp. had different percent of lysis when treated with lysozyme; this may be due to the cell wall components having strain-dependent differences [24]. In this study, lysozyme completely inhibited both autoaggregation of $S$. mutans ATCC $25175^{\mathrm{TM}}$ and coaggregation between L. gasseri and S. mutans ATCC $25175^{\mathrm{TM}}$. It is suggested that lysozyme inhibits the aggregation of $S$. mutans, whether autoaggregation or coaggregation with other bacteria. This corresponds with previous studies, in which lysozyme activity in the oral cavity has mainly been characterized against oral streptococci especially $S$. mutans [25-27]. For GI tract enzymes, only trypsin treatment significantly decreased the coaggregation of L. gasseri and S. mutans compared to the control group. This effect may be due to the digestion of proteins on the cell surface.

It can be concluded from our result that $L$. gasseri can survive and exhibit aggregation and adhesion ability under the various oral and GI tract enzymes conditions, excluding coaggregation with S. mutans after lysozyme treatment. Tolerance to these digestive enzymes is possibly considered as an important property for the development into probiotics.

\section{Effect of pH, sugars, and ions}

The aggregation and adhesion abilities of $L$. gasseri strains after treatment with $\mathrm{pH}$, sugars, and ions are shown in Table 3. Concerning the aggregation ability, the present study indicated that calcium ion and magnesium ion significantly increased both autoaggregation of L. gasseri and coaggregation between L. gasseri and S. mutans ATCC $25175^{\mathrm{TM}}$, while $\mathrm{pH} 4.0$ increased only the coaggregation ability. Among the effect of sugars on aggregation abilities, lactose was the only one that significantly reduced both 
http://wjst.wu.ac.th

autoaggregation and coaggregation, while glucose and sucrose significantly decreased the coaggregation ability. It was noted that some factors, such as $\mathrm{pH} 4.0$, glucose, and sucrose, had a significant effect on coaggregation between the bacterial cells, whereas the autoaggregation of L. gasseri was not affected. It may be the influence of autoaggregation of $S$. mutans that increased from 35.75 to $72.19 \%$ at $\mathrm{pH} 4.0$ and decreased after treatment with glucose and sucrose from 35.75 to 26.95 and $12.32 \%$, respectively.

Regarding adhesion ability, total adhesion and internalization were significantly increased by $\mathrm{pH}$ 4.0, $\mathrm{pH} 8.0$, and calcium ion while magnesium ion significantly increased only the internalization. The results showed that neither kind of sugar significantly affected adhesion.

Lactobacillus generally survives well under acidic conditions [28-30]. Therefore, it is not surprising that $L$. gasseri can aggregate and adhere at low $\mathrm{pH}$ conditions. But it is noteworthy from this experiment, that $L$. gasseri also increased its adhesion ability in basic conditions (at $\mathrm{pH} 8.0$ ). That may be the reason for the high prevalence of L. gasseri in periodontal tissue [3] which has a pH range between 6.5 - 8.5 [31].

Calcium and magnesium ions are inorganic substances that can be found in the food. Moreover, these ions are components of the inorganic part of human saliva and are involved in the formation of teeth [32]. It has previously been demonstrated that these ions are also important for adhesion and aggregation properties [33-35]. The results in this study imply that the aggregation and adhesion abilities of L. gasseri can be induced and also increased when in an environment that contains calcium and magnesium ions such as in saliva or in calcium-rich food or dairy products.

Regarding the selected sugar, glucose sucrose and lactose are the main sugars obtained from food. Glucose and sucrose are commonly added to many processed foods, while lactose is found naturally in milk and dairy products [36]. The findings of the present study indicated that the sugars especially lactose had the effect of decreasing the aggregation of L. gasseri and S. mutans ATCC $25175^{\mathrm{TM}}$. Many studies have demonstrated that lactose inhibited aggregation between the cells of both gram-positive and gramnegative bacteria via the lectin-carbohydrate interaction mechanism of cell surface elements [37-41]. In addition, other studies have suggested that L. gasseri was not adapted to grow well in a milk environment $[42,43]$, which may explain the phenomenon above.

Table 2 The effect of the treatment with enzymes on aggregation and adhesion abilities ${ }^{\mathrm{a}}$.

\begin{tabular}{ccccccc}
\hline \multirow{2}{*}{ Factors } & \multicolumn{3}{c}{ \% Aggregation ability } & \multicolumn{3}{c}{ \% Adhesion ability $^{\mathbf{c}}$} \\
\cline { 2 - 7 } & $\begin{array}{c}\text { Autoaggregation } \\
\text { L. gasseri }\end{array}$ & $\begin{array}{c}\text { Autoaggregation } \\
\text { S. mutans }\end{array}$ & $\begin{array}{c}\text { Coaggregation }^{\mathbf{b}} \\
\text { Control }\end{array}$ & $\begin{array}{c}\text { Total } \\
\text { adhesion }\end{array}$ & Internalization & Externalization \\
\hline Enzymes & $(69.09 \pm 9.50$ & 35.75 & $50.94 \pm 7.15$ & $67.73 \pm 11.22$ & $40.72 \pm 11.82$ & $27.01 \pm 8.30$ \\
& & $(33.10)$ & $(52.81)$ & $(68.83)$ & $(37.83)$ & $(26.19)$ \\
Amylase & $78.03 \pm 9.01$ & 31.17 & $74.60 \pm 11.77$ & $65.99 \pm 7.86$ & $40.12 \pm 8.40$ & $25.86 \pm 9.12$ \\
& $\left(80.42^{*}\right)$ & $(31.50)$ & $\left(78.27^{* *}\right)$ & $(65.66)$ & $(39.15)$ & $(27.39)$ \\
Lysozyme & $71.00 \pm 13.83$ & 0.00 & 0.00 & $65.33 \pm 8.98$ & $40.99 \pm 6.59$ & $24.33 \pm 7.29$ \\
& $(72.92)$ & $(0.00)$ & $\left(0.00^{* *}\right)$ & $(65.48)$ & $(41.22)$ & $(24.58)$ \\
Trypsin & $64.67 \pm 8.39$ & 39.33 & $46.35 \pm 6.14$ & $67.47 \pm 6.88$ & $39.84 \pm 8.78$ & $27.63 \pm 7.25$ \\
& $(62.18)$ & $(38.80)$ & $\left(46.01^{*}\right)$ & $(70.21)$ & $(36.36)$ & $(29.00)$ \\
Pepsin & $66.68 \pm 8.07$ & 43.33 & $48.95 \pm 6.93$ & $63.65 \pm 5.01$ & $36.59 \pm 7.66$ & $27.06 \pm 5.67$ \\
& $(67.00)$ & $(42.90)$ & $(49.04)$ & $(64.03)$ & $(35.11)$ & $(28.43)$ \\
Lipase & $66.78 \pm 8.22$ & 40.71 & $50.13 \pm 6.94$ & $63.03 \pm 5.97$ & $36.75 \pm 6.89$ & $26.27 \pm 5.86$ \\
& $(67.24)$ & $(40.70)$ & $(48.65)$ & $(62.53)$ & $(36.21)$ & $(27.02)$ \\
\hline
\end{tabular}

${ }^{a}$ Data are expressed as mean \pm SD (median)

${ }^{\mathrm{b}}$ Coaggregation between L. gasseri strains and S. mutans ATCC $25175^{\mathrm{TM}}$

${ }^{c}$ Adhesion ability for L. gasseri strains with oral squamous carcinoma cell line, H357 keratinocyte cells, in

Dulbecco's modified Eagle's medium

*Significant differences at $p$-value $<0.05$ between control and tested group

${ }^{* *}$ Significant differences at $p$-value $<0.001$ between control and tested group 
http://wjst.wu.ac.th

Table 3 Effect of $\mathrm{pH}$, sugars and ions on the aggregation and adhesion abilities ${ }^{\mathrm{a}}$.

\begin{tabular}{|c|c|c|c|c|c|c|}
\hline \multirow[b]{2}{*}{ Factors } & \multicolumn{3}{|c|}{$\%$ Aggregation ability } & \multicolumn{3}{|c|}{$\%$ Adhesion ability $^{\mathrm{c}}$} \\
\hline & $\begin{array}{c}\text { Autoaggregation } \\
\text { L. gasseri } \\
\end{array}$ & $\begin{array}{c}\text { Autoaggregation } \\
\text { S. mutans } \\
\end{array}$ & Coaggregation $^{b}$ & Total adhesion & Internalization & Externalization \\
\hline Control & $\begin{array}{c}70.09 \pm 9.50 \\
(69.76)\end{array}$ & $\begin{array}{l}35.75 \\
(33.10)\end{array}$ & $\begin{array}{l}50.94 \pm 7.15 \\
(52.81)\end{array}$ & $\begin{array}{c}67.73 \pm 11.22 \\
(68.83)\end{array}$ & $\begin{array}{l}40.72 \pm 11.82 \\
\quad(37.83)\end{array}$ & $\begin{array}{l}27.01 \pm 8.30 \\
(26.19)\end{array}$ \\
\hline \multicolumn{7}{|l|}{$\mathrm{pH}$} \\
\hline $\mathrm{pH} 4.0$ & $\begin{array}{c}75.97 \pm 9.40 \\
(76.73)\end{array}$ & $\begin{array}{l}72.19 \\
(73.98)\end{array}$ & $\begin{array}{c}63.39 \pm 11.87 \\
\left(58.31^{*}\right)\end{array}$ & $\begin{array}{c}83.26 \pm 6.49 \\
\left(84.28^{* *}\right)\end{array}$ & $\begin{array}{l}53.27 \pm 7.35 \\
\left(54.13^{* *}\right)\end{array}$ & $\begin{array}{c}29.99 \pm 9.77 \\
(30.17)\end{array}$ \\
\hline $\mathrm{pH} 8.0$ & $\begin{array}{l}70.54 \pm 9.86 \\
(71.26)\end{array}$ & $\begin{array}{l}47.58 \\
(47.75)\end{array}$ & $\begin{array}{l}51.61 \pm 5.54 \\
(51.20)\end{array}$ & $\begin{array}{c}78.78 \pm 5.63 \\
\left(78.24^{*}\right)\end{array}$ & $\begin{array}{c}50.53 \pm 7.75 \\
\left(48.92^{*}\right)\end{array}$ & $\begin{array}{c}28.25 \pm 8.76 \\
(28.71)\end{array}$ \\
\hline \multicolumn{7}{|l|}{ Sugars } \\
\hline Glucose & $\begin{array}{c}66.67 \pm 14.08 \\
(66.67)\end{array}$ & $\begin{array}{l}26.95 \\
(28.55)\end{array}$ & $\begin{array}{l}35.27 \pm 11.72 \\
\left(34.83^{* *}\right)\end{array}$ & $\begin{array}{c}67.83 \pm 11.00 \\
(66.54)\end{array}$ & $\begin{array}{c}41.76 \pm 9.17 \\
(39.94)\end{array}$ & $\begin{array}{c}26.07 \pm 9.58 \\
(26.87)\end{array}$ \\
\hline Sucrose & $\begin{array}{c}67.77 \pm 15.00 \\
(71.86)\end{array}$ & $\begin{array}{l}12.32 \\
(12.37)\end{array}$ & $\begin{array}{l}35.70 \pm 15.83 \\
\quad\left(32.74^{*}\right)\end{array}$ & $\begin{array}{c}66.53 \pm 10.32 \\
(65.60)\end{array}$ & $\begin{array}{c}41.91 \pm 11.98 \\
(40.26)\end{array}$ & $\begin{array}{c}24.62 \pm 7.33 \\
(26.03)\end{array}$ \\
\hline Lactose & $\begin{array}{l}57.12 \pm 16.34 \\
\left(58.56^{*}\right)\end{array}$ & $\begin{array}{l}18.44 \\
(18.03)\end{array}$ & $\begin{array}{c}31.60 \pm 10.37 \\
\left(36.56^{* *}\right)\end{array}$ & $\begin{array}{c}67.34 \pm 9.21 \\
(68.25)\end{array}$ & $\begin{array}{c}41.81 \pm 9.99 \\
(40.62)\end{array}$ & $\begin{array}{l}25.53 \pm 8.35 \\
(24.81)\end{array}$ \\
\hline \multicolumn{7}{|l|}{ Ions } \\
\hline Calcium & $\begin{array}{l}84.55 \pm 6.81 \\
\left(83.70^{* *}\right)\end{array}$ & $\begin{array}{l}43.07 \\
(44.90)\end{array}$ & $\begin{array}{l}57.64 \pm 8.06 \\
\left(60.21^{*}\right)\end{array}$ & $\begin{array}{l}83.62 \pm 5.56 \\
\left(82.10^{* *}\right)\end{array}$ & $\begin{array}{l}54.79 \pm 9.85 \\
\left(53.24^{* *}\right)\end{array}$ & $\begin{array}{c}28.83 \pm 10.00 \\
\quad(30.47)\end{array}$ \\
\hline Magnesium & $\begin{array}{c}82.52 \pm 9.31 \\
\left(81.74^{*}\right)\end{array}$ & $\begin{array}{l}32.06 \\
(32.20) \\
\end{array}$ & $\begin{array}{c}55.95 \pm 6.52 \\
\left(57.53^{*}\right)\end{array}$ & $\begin{array}{c}74.52 \pm 6.97 \\
(76.23)\end{array}$ & $\begin{array}{c}47.23 \pm 8.03 \\
\left(47.52^{*}\right)\end{array}$ & $\begin{array}{c}27.29 \pm 7.80 \\
(27.44)\end{array}$ \\
\hline
\end{tabular}

${ }^{a}$ Data are expressed as mean \pm SD (median)

${ }^{\mathrm{b}}$ Coaggregation between L. gasseri strains and S. mutans ATCC $25175^{\mathrm{TM}}$

${ }^{c}$ Adhesion ability for L. gasseri strains with oral squamous carcinoma cell line, H357 keratinocyte cells, in Dulbecco's modified Eagle's medium

*Significant differences at $p$-value $<0.05$ between control and tested group

${ }^{* *}$ Significant differences at $p$-value $<0.001$ between control and tested group

\section{Conclusions}

Probiotic strains with good abilities to aggregate and adhere to oral epithelial cells could be better suited to colonize the oral cavity. However, aggregation and adhesion abilities are dependent on environmental factors. Moreover, the cell surface properties of bacteria are thought to play an important role in these abilities. For this, L. gasseri used the cell surface-related protein components for the aggregation and internalized adhering abilities. L. gasseri can survive and exhibit aggregation and adhesion ability under various environmental conditions. These traits could be used for the preliminary screening of other potential probiotic candidates with possible anti-caries properties.

\section{Acknowledgements}

This project was supported by the National Research Council of Thailand (DEN600045b), the Graduate School, Prince of Songkla University, and a scholarship from the Office of the Higher Education Commission. The authors would like to thank staff members at the Oral Microbiology Laboratory, Faculty of Dentistry, Prince of Songkla University, for their help and facilitating the use of equipment. Assistances in some of the experiments by Miss Benchamat Sophatha, Miss Nuntiya Pahumunto, and Miss Penthip Saetang are also gratefully acknowledged. 
http://wjst.wu.ac.th

\section{References}

[1] K Selle and TR Klaenhammer. Genomic and phenotypic evidence for probiotic influences of Lactobacillus gasseri on human health. FEMS Microbiol. Rev. 2013; 37, 915-35.

[2] C Badet and NB Thebaud. Ecology of lactobacilli in the oral cavity: A review of literature. Open Microbiol. J. 2008; 2, 38-48.

[3] P Koll-Klais, R Mandar, E Leibur, H Marcotte, L Hammarstrom and M Mikelsaar. Oral lactobacilli in chronic periodontitis and periodontal health species composition and antimicrobial activity. Oral Microbiol. Immunol. 2005; 20, 354-61.

[4] R Wall, G Fitzgerald, S Hussey, T Ryan, B Murphy, P Ross and C Stanton. Genomic diversity of cultivable Lactobacillus populations residing in the neonatal and adult gastrointestinal tract. FEMS Microbiol. Ecol. 2007; 59, 127-37.

[5] CL Ferreira, L Grzeskowiak, MC Collado and S Salminen. In vitro evaluation of Lactobacillus gasseri strains of infant origin on adhesion and aggregation of specific pathogens. J. Food Prot. $2011 ; 74,1482-7$.

[6] S Fujimura, A Watanabe, K Kimura and M Kaji. Probiotic mechanism of Lactobacillus gasseri OLL2716 strain against Helicobacter pylori. J. Clin. Microbiol. 2012; 50, 1134-6.

[7] K Nishiyama, Y Seto, K Yoshioka, T Kakuda, S Takai, Y Yamamoto and T Mukai. Lactobacillus gasseri SBT2055 reduces infection by and colonization of Campylobacter jejuni. PloS One 2014; 29, e108827.

[8] R Kobayashi, T Kobayashi, F Sakai, T Hosoya, M Yamamoto and T Kurita-Ochiai. Oral administration of Lactobacillus gasseri SBT2055 is effective in preventing Porphyromonas gingivalis-accelerated periodontal disease. Sci Rep. 2017; 7, 545.

[9] NR Vestman, N Timby, PL Holgerson, CA Kressirer, R Claesson, M Domellof, C Ohman, AC Tanner, O Hernell and I Johansson. Characterization and in vitro properties of oral lactobacilli in breastfed infants. BMC Microbiol. 2013; 13, 193.

[10] MS Amez, JL Lopez, AE Devesa, RA Montero and EJ Salas. Probiotics and oral health: A systematic review. Med. Oral Patol. Oral Cir. Bucal. 2017; 22, e282-e288.

[11] S Piwat, B Sophatha and R Teanpaisan. An assessment of adhesion, aggregation and surface charges of Lactobacillus strains derived from the human oral cavity. Lett. Appl. Microbiol. 2015; 61, 98-105.

[12] MC Collado, J Meriluoto and S Salminen. Adhesion and aggregation properties of probiotic and pathogen strains. Eur. Food Res. Tech. 2008; 226, 1065-73.

[13] AH Rickard, P Gilbert, NJ High, PE Kolenbrander and PS Handley. Bacterial coaggregation: An integral process in the development of multi-species biofilms. Trends Microbiol. 2003; 11, 94-100.

[14] R Sengupta, E Altermann, RC Anderson, WC McNabb, PJ Moughan and NC Roy. The role of cell surface architecture of lactobacilli in host-microbe interactions in he gastrointestinal tract. Mediat. Inflamm. 2013; 2013, 237921.

[15] H Ekmekci, B Aslim and DO Darilmaz. Some factors affecting the autoaggregation ability of vaginal lactobacilli isolated from Turkish women. Arch. Biol. Sci. 2009; 61, 407-12.

[16] JD Greene and TR Klaenhammer. Factors involved in adherence of lactobacilli to human Caco-2 cells. Appl. Environ. Microbiol. 1994; 60, 4487-94.

[17] S Piwat, S Thitasomakul, A Thearmontree and G Dahlén. Lactobacillus species and genotypes associated with dental caries in Thai preschool children. Mol. Oral Microbiol. 2010; 25, 157-64.

[18] C Lang, M Bottner, C Holz, M Veen, M Ryser, A Reindl, M Pompejus and JM Tanzer. Specific Lactobacillus/Mutans Streptococcus co-aggregation. J. Dent. Res. 2010; 89, 175-9.

[19] B Kos, J Suskovic, S Vukovic, M Simpraga, J Frece and S Matosic. Adhesion and aggregation ability of probiotic strain Lactobacillus acidophilus M92. J. Appl. Microbiol. 2003; 94, 981-7.

[20] S Kintarak, SA Whawell, PM Speight, S Packer and SP Nair. Internalization of Staphylococcus aureus by human keratinocytes. Infect. Immun. 2004; 72, 5668-75.

[21] CM Santos, MC Pires, TL Leao, ZP Hernandez, ML Rodriguez, AK Martins, LS Miranda, FS Martins and JR Nicoli. Selection of Lactobacillus strains as potential probiotics for vaginitis treatment. Microbiology 2016; 162, 1195-207. 
http://wjst.wu.ac.th

[22] M Edgerton and SE Koshlukova. Salivary histatin 5 and its similarities to the other antimicrobial proteins in human saliva. Adv. Dent. Res. 2000; 14, 16-21.

[23] MP Chapot-Chartier and S Kulakauskas. Cell wall structure and function in lactic acid bacteria. Microb. Cell Factories 2014; 13, S9.

[24] BM Chassy and A Giuffrida. Method for the lysis of Gram-positive, asporogenous bacteria with lysozyme. Appl. Environ. Microbiol. 1980; 39, 153-8.

[25] VJ Iacono, BJ MacKay, S DiRienzo and JJ Pollock. Selective antibacterial properties of lysozyme for oral microorganisms. Infect. Immun. 1980; 29, 623-32.

[26] NJ Laible and GR Germaine. Bactericidal activity of human lysozyme, muramidase-inactive lysozyme, and cationic polypeptides against Streptococcus sanguis and Streptococcus faecalis: Inhibition by chitin oligosaccharides. Infect. Immun. 1985; 48, 720-8.

[27] FB de Andrade, JC de Oliveira, MT Yoshie, BM Guimaraes, RB Goncalves and WD Schwarcz. Antimicrobial activity and synergism of lactoferrin and lysozyme against cariogenic microorganisms. Braz. Dent. J. 2014; 25, 165-9.

[28] KS Vinusha, K Deepika, TS Johnson, GK Agrawal and R Rakwal. Proteomic studies on lactic acid bacteria: A review. Biochem. Biophys. Rep. 2018; 14, 140-8.

[29] K Papadimitriou, A Alegria, PA Bron, M de Angelis, M Gobbetti, M Kleerebezem, JA Lemos, DM Linares, P Ross, C Stanton, F Turroni, D Sinderen, P Varmanen, M Ventura, M Zuniga, E Tsakalidou and J Kok. Stress physiology of lactic acid bacteria. Microbiol. Mol. Biol. Rev. 2016; 80, 837-90.

[30] EJ Quinto, P Jimenez, I Caro, J Tejero, J Mateo and T Girbes. Probiotic lactic acid bacteria: A review. Food Nutr. Sci. 2014; 05, 1765-75.

[31] RT Kung, B Ochs and JM Goodson. Temperature as a periodontal diagnostic. J. Clin. Periodontol. 1990; 17, 557-63.

[32] MZ Shukria and SR Ali. The relationship between calcium, magnesium and inorganic phosphate of human mixed saliva and dental caries. Mustansiria Dent. J. 2007; 4, 157-61

[33] PA Lambert, IC Hancock and J Baddiley. The interaction of magnesium ions with teichoic acid. Biochem. J. 1975; 149, 519-24.

[34] B Song and LG Leff. Influence of magnesium ions on biofilm formation by Pseudomonas fluorescens. Microbiol. Res. 2006; 161, 355-61.

[35] N Larsen, P Nissen and WG Willats. The effect of calcium ions on adhesion and competitive exclusion of Lactobacillus ssp. and E. coli O138. Int. J. Food Microbiol. 2007; 114, 113-9.

[36] R Touger-Decker and CV Loveren. Sugar and dental caries. Am. J. Clin. Nutr. 2003; 78, 881-92.

[37] FC McIntire, AE Vatter, J Baros and J Arnold. Mechanism of coaggregation between Actinomyces viscosus T14V and Streptococcus sanguis 34. Infect. Immun. 1978; 21, 978-88.

[38] PE Kolenbrander and BL Williams. Lactose-reversible coaggregation between oral actinomycetes and Streptococcus sanguis. Infect. Immun. 1981; 33, 95-102.

[39] PE Kolenbrander. Surface recognition among oral bacteria: Multigeneric coaggregations and their mediators. Crit. Rev. Microbiol. 1989; 17, 137-59.

[40] PE Kolenbrander and RN Andersen. Inhibition of coaggregation between Fusobacterium nucleatum and Porphyromonas (Bacteroides) gingivalis by lactose and related sugars. Infect. Immun. 1989; 57, 3204-9.

[41] SD Bentzmann, A Varrot and A Imberty. Monitoring lectin interactions with carbohydrates. Meth. Mol. Biol. 2014; 1149, 403-14.

[42] L Avonts, EV Uytven and LD Vuyst. Cell growth and bacteriocin production of probiotic Lactobacillus strains in different media. Int. Dairy J. 2004; 14, 947-55.

[43] K Arakawa, K Matsunaga, S Takihiro, A Moritoki, S Ryuto, Y Kawai, T Masuda and T Miyamoto. Lactobacillus gasseri requires peptides, not proteins or free amino acids, for growth in milk. $J$. Dairy Sci. 2015; 98, 1593-603. 